\title{
ION ASSOCIATION. IV. EFFECT OF SODIUM SULFATE INFUSION \\ ON RENAL CLEARANCE AND BODY RETENTION OF INJECTED RADIOSTRONTIUM IN DOGS *
}

\author{
By MACKENZIE WALSER, JOHN W. PAYNE $\dagger$ AND ANN A. BROWDER $\ddagger$ \\ (From the Department of Pharmacology and Experimental Therapeutics, The Johns Hopkins \\ University School of Medicine, Baltimore, Md.)
}

(Submitted for publication March 25, 1960 ; accepted September 30, 1960)

The removal of toxic metals from the body by administering appropriate complexing agents has been the subject of intensive study in recent years. The agents employed have usually been organic chelating compounds, chosen because of their affinity for the toxic metal to be removed. This approach has been highly successful in the case of some metals but of limited success in the case of radioactive strontium. The chemical similarity of strontium to calcium renders difficult the search for a compound which will remove strontium in preference to calcium (3-5).

Since calcium and strontium are apparently handled in similar fashion by the kidney (6-11), increased calcium excretion is associated with increased strontium excretion. Therefore, a more successful approach has been the administration of agents known to increase calcium excretion, including calcium salts, ammonium chloride, sodium citrate, parathyroid extract, and a variety of anions which chelate both calcium and strontium $(8,12$ $30)$. Even when these substances are administered, a major portion of the filtered loads of both ions continues to be reabsorbed by the renal tubules. Consequently, it is difficult to achieve very high rates of calcium or strontium excretion by these means. Although retention of radiostrontium may be considerably reduced by administering some of these agents either prior to or simultaneously with the isotope, therapy instituted after exposure removes only a small amount.

The use of external (31) or peritoneal (32) dialysis in dogs has been somewhat more success-

\footnotetext{
* This work was supported by an institutional grant from the American Cancer Society and by U. S. Public Health Service Grant (A-2306). Portions of this work have been presented in abstract form $(1,2)$.

† Work performed during support by U. S. Public Health Service Experimental Training Grant (2R9C).

$\ddagger$ Work performed during tenure of a National Science Foundation Student Fellowship.
}

ful, 30 to 40 per cent of the dose being removed by therapy instituted after 1 hour of exposure (31). However, the amount of isotope mobilized was only slightly greater than the amount estimated to be present in the extracellular fluid. Therapy instituted after 12 hours removed less than 12 per cent of the remaining radiostrontium (31).

The marked effect of sulfate infusion on the renal excretion of both calcium and magnesium (33, 34) suggested the use of sodium sulfate in order to accelerate strontium excretion. The mechanism by which sulfate augments the excretion of alkaline earth cations, discussed in a previous paper (34), is apparently related to the formation of electrostatic ion-pairs, which differ from metalchelate compounds in that covalent bonding is not thought to occur (35). Although the dissociation constant of the strontium sulfate ion-pair has apparently not been reported, it is probably close to the dissociation constants of the calcium sulfate and magnesium sulfate ion-pairs, both of which are approximately $0.06 \mathrm{M}$ at ionic strength $0.16 \mathrm{M}$ (36).

Therefore strontium ions, in common with calcium and magnesium ions, may be poorly reabsorbed by the renal tubules when paired electrostatically with sulfate ions. In this manner, renal excretion of strontium may be accelerated by sulfate infusion.

Even the complete removal of radiostrontium from the extracellular fluid by means of renal excretion would be of little benefit unless mobilization of isotope retained in the skeleton and in the tissues also occurred. It has been shown repeatedly that the fraction of the remaining isotope in the blood stream falls rapidly without therapy $(6,8,10-12,21,37,38)$. Schulert and coworkers (39) have recently reported that the soft tissues contain approximately as much isotope as the skeleton during the first few weeks. 
TABLE I

Summary of experimental procedures

\begin{tabular}{|c|c|c|c|c|c|c|c|c|c|c|c|c|}
\hline \multirow[b]{2}{*}{ Dog } & \multirow[b]{2}{*}{$\mathrm{Wt}$} & \multirow[b]{2}{*}{ Isotope } & \multirow[b]{2}{*}{ Dose } & \multirow[b]{2}{*}{$\begin{array}{l}\text { Period of } \\
\text { infusion }\end{array}$} & \multirow[b]{2}{*}{$\begin{array}{l}\text { Rates of } \\
\text { infusion }\end{array}$} & \multicolumn{6}{|c|}{ Composition of infusion } & \multirow{2}{*}{$\begin{array}{c}\text { Plasma } \\
\mathrm{SO}_{4} \\
\text { range }\end{array}$} \\
\hline & & & & & & $\mathrm{Ca}$ & $\mathrm{Mg}$ & $\mathrm{K}$ & $\mathrm{SO}_{4}$ & $\begin{array}{l}\text { Ace- } \\
\text { tate }\end{array}$ & $\begin{array}{c}\text { Man- } \\
\text { nitol }\end{array}$ & \\
\hline & $\mathrm{kg}$ & & $\mu c$ & $\begin{array}{l}\text { hrs after } \\
\text { injection }\end{array}$ & $m l / \min$ & \multicolumn{6}{|c|}{ mmoles $/ L$} & mmoles $/ L$ \\
\hline $\begin{array}{l}\mathrm{D} \\
\mathrm{E} \\
\mathrm{M} \\
\mathrm{Q} \\
\mathrm{R} 1 \\
\mathrm{R} 2 \\
\mathrm{~S} \\
\mathrm{~T} \\
\mathrm{U} \\
\mathrm{V}\end{array}$ & $\begin{array}{r}9 \\
11 \\
23 \\
11 \\
19 \\
19 \\
11 \\
11 \\
11 \\
19\end{array}$ & $\begin{array}{l}\mathrm{Sr}^{89} \\
\mathrm{Sr}^{89} \\
\mathrm{Sr}^{89} \\
\mathrm{Sr}^{85} \\
\mathrm{Sr}^{85} \\
\mathrm{Sr}^{85} \\
\mathrm{Sr}^{85} \\
\mathrm{Sr}^{85} \\
\mathrm{Sr}^{85} \\
\mathrm{Sr}^{85}\end{array}$ & $\begin{array}{c}200 \\
200 \\
200 \\
50 \\
50 \\
50 \\
50 \\
37.5 \\
37.5 \\
12\end{array}$ & $\begin{array}{c}14-17 \\
168-188 \\
72-80 \\
14-24 \\
18-25 \\
41-52 \\
4-8 \\
20-24 \\
21-24 \\
2.5-5\end{array}$ & $\begin{array}{c}13 \\
13 \\
25 \\
20 \\
16 \\
7 \\
20 \\
10 \\
15-35 \\
15-23\end{array}$ & $\begin{array}{l}0,5^{*} \\
3 \\
3 \\
2 \\
4 \\
0 \\
0 \\
0,5^{*} \\
0,5^{*} \\
3\end{array}$ & $\begin{array}{l}2 \\
3 \\
3 \\
2 \\
4 \\
0 \\
5 \\
2 \\
2 \\
3\end{array}$ & $\begin{array}{l}16 \\
16 \\
0,16^{*} \\
16 \\
0 \\
0 \\
0 \\
16 \\
16 \\
8\end{array}$ & $\begin{array}{r}100 \\
100 \\
93 \\
100 \\
90 \\
100 \\
100 \\
100 \\
100 \\
97\end{array}$ & $\begin{array}{r}\mathbf{0} \\
\mathbf{0} \\
\mathbf{0} \\
\mathbf{0} \\
18 \\
20 \\
\mathbf{0} \\
\mathbf{0} \\
\mathbf{0} \\
\mathbf{0}\end{array}$ & $\begin{array}{l}\mathbf{0} \\
\mathbf{0} \\
\mathbf{0} \\
\mathbf{0} \\
\mathbf{0} \\
\mathbf{0} \\
\mathbf{0} \\
\mathbf{0} \\
\mathbf{0} \\
\mathbf{5 0}\end{array}$ & $\begin{array}{r}20-23 \\
13-24 \\
13-27 \\
17-26 \\
8-18 \\
6-10 \\
17-20 \\
17-29 \\
21-29\end{array}$ \\
\hline
\end{tabular}

* In these experiments infusions of two different compositions were employed in the order indicated.

There are two ways in which an agent such as sulfate might mobilize skeletal deposits of radiostrontium. First, the removal of circulating isotope would lead to exchange between circulating calcium ions and radiostrontium atoms in the crystal lattice of bone. Secondly, the production of negative calcium balance and the reduced plasma concentration of free calcium ions would lead to some demineralization of bone. Similar considerations might apply to extraskeletal repositories of calcium and radiostrontium.

The present experiments were conducted to determine the effect of sulfate infusion on the renal clearance and bodily retention of radiostrontium in dogs. Because of varying nutrition (and possibly age), the individual dogs differed in the amount of radiostrontium retained before sulfate infusion and therefore in the percentage mobilized during the infusion. Nevertheless, a uniform relationship between radiostrontium clearance and sulfate excretion was observed, irrespective of the interval before therapy, the percentage of isotope remaining, or the amounts of calcium and magnesium in the infused solution. At high rates of infusion, renal tubular reabsorption of strontium almost ceased.

\section{METHODS}

Carrier-free isotopes of strontium, ${ }^{1} \mathrm{Sr}^{85}$ or $\mathrm{Sr}^{80}$, obtained as $\mathrm{SrCl}_{2}$ in $\mathrm{HCl}$ were appropriately diluted and injected intravenously into 9 female mongrel dogs weighing 10 to $18 \mathrm{~kg}$. These animals, obtained from the pound, appeared to be healthy and fully grown but were in vary-

${ }^{1} \mathrm{Sr}^{85}$ was obtained from Nuclear Science and Engineering Corporation, Pittsburgh, $\mathrm{Pa}$. $\mathrm{Sr}^{80}$ was obtained from Oak Ridge National Laboratories. ing states of nutrition. They were placed in metabolism cages and urine and stool collections begun. The dogs were fed their usual diet of pellets. During the clearance measurements, urine was collected by indwelling urethral catheters, and each sample was analyzed separately. The technique of the clearance experiments and methods of analysis of calcium, creatinine and sulfate are described elsewhere $(34,40,41)$. Stool samples were homogenized with water in a blender.

Table I summarizes the isotope dosages, periods of infusion, and infusion composition in each experiment. One $\operatorname{dog}(\mathrm{R})$ was given a single injection but was treated on two successive occasions; these two experiments are designated $R 1$ and $R 2$. In five experiments ( D, $Q, T, S$ and $\mathrm{V}$ ) one or two control collection periods preceding sulfate infusion were obtained. In all ten, isotope excretion was measured during sulfate infusion. The duration of the infusion varied from 2.5 hours in the animal treated 2.5 hours after injection, to 20 hours in the dog treated 1 week after injection; in the others, the duration of the infusion averaged 6 hours.

$\mathrm{Sr}^{85}$ was determined in a scintillation counter equipped with a well. The radioactivity of $2-\mathrm{ml}$ samples of plasma, urine, or homogenized stool suspension, counted for 10,000 counts or more, was compared with that of an aliquot of the injected solution, after correction for background. $\mathrm{Sr}^{89}$ was determined by evaporating aliquots to dryness on planchets fitted with absorbent paper discs. One $\mathrm{ml}$ of urine or an aliquot of the injected solution was mixed with $0.5 \mathrm{ml}$ of normal plasma in the planchet in order to make self-absorption uniform; when plasma or stool suspension was analyzed, a $0.5 \mathrm{ml}$ aliquot was mixed with $1 \mathrm{ml}$ of water. Radioactivity was determined with an end-window GM counter. Duplicate aliquots of plasma samples yielded results differing by 1.5 per cent or less.

\section{RESULTS}

1. The increase in radiostrontium excretion during sulfate infusion. In five of the ten experiments, control periods were obtained during which 
TABLE II

Increase in radiostrontium excretion during first 30 to 60 minutes of sulfate infusion

\begin{tabular}{|c|c|c|c|c|c|}
\hline & \multicolumn{2}{|c|}{ Urine flow } & \multicolumn{3}{|c|}{ Sr excretion } \\
\hline & Control & $\overline{\text { Sulfate }}$ & Control & Sulfate & Change \\
\hline & $m l / m i n$ & $m l / m i n$ & $\mu c / \min$ & $\mu \mathrm{c} / \mathrm{min}$ & \\
\hline $\begin{array}{l}\mathrm{D} \\
Q \\
S \\
\mathrm{~T} \\
\mathrm{~V}\end{array}$ & $\begin{array}{l}0.7 \\
0.7 \\
1.1 \\
0.3 \\
1.5\end{array}$ & $\begin{array}{r}11.6 \\
10.6 \\
9.9 \\
8.5 \\
20.6\end{array}$ & $\begin{array}{l}0.0186 \\
0.0025 \\
0.0032 \\
0.0011 \\
0.0054\end{array}$ & $\begin{array}{l}0.506 \\
0.015 \\
0.0916 \\
0.018 \\
0.208\end{array}$ & $\begin{array}{r}27 \times \\
6 \times \\
29 \times \\
16 \times \\
39 \times\end{array}$ \\
\hline
\end{tabular}

the dogs received either no intravenous fluids or a solution of creatinine at $1 \mathrm{ml}$ per minute. Urine was obtained by indwelling catheter. The rate of isotope excretion in the first 30 to 60 minutes of sulfate infusion was 6 to 40 times greater than that in the control periods (Table II). This increment cannot be attributed to washout of concentrated urine from the renal tubules and pelvis, since urinary strontium concentration either increased or fell only slightly. In one additional dog, infusion of hypertonic sulfate solution followed infusion of hypertonic glucose (Table III). Despite falling urine flow, excretion of strontium (as well as calcium and magnesium) rose many fold when sulfate was administered.

In all of the dogs, the increase in radiostrontium excretion following infusion of sulfate led to a progressive decline in plasma radioactivity. Consequently, isotope excretion rate fell in subsequent collection periods. The effectiveness of sulfate (or of any other agent) in removing radiostrontium from the extracellular fluid is better evaluated by the change in isotope clearance, which in theory should be independent of isotope concentration.

2. The clearance of radiostrontium during sulfate infusion. In nine of the ten experiments, the renal clearances of radiostrontium, creatinine and sulfate were determined simultaneously during sulfate infusion. Strontium clearance was calculated without correction for protein-binding (see below). In normal dogs or humans, strontium clearance calculated in this manner has been reported to be two to five times calcium clearance, or approximately $3 \mathrm{ml}$ per $100 \mathrm{ml}$ of glomerular filtrate $(\mathrm{GF})(6,7,11,23)$. In 14 collection periods in six normal dogs undergoing water, glucose or mannitol diuresis, radiostrontium clearance averaged $5 \mathrm{ml}$ per $100 \mathrm{ml}$ of GF. This value represents the tubular reabsorption of over 90 per cent of the filtered isotope.

During sulfate infusion, strontium clearance increased to unprecedented levels, reaching values over $60 \mathrm{ml}$ per $100 \mathrm{ml}$ of $\mathrm{GF}$. The relationship between radiostrontium clearance and urinary sulfate excretion is depicted in Figure 1. Both parameters are expressed per $100 \mathrm{ml}$ of $\mathrm{GF}$ in order to compare animals of different size. Despite considerable variation in the size of the dogs and in the interval between isotope administration and start of therapy (see Table I), a uniform relationship is observed, which appears to be linear. This relationship resembles that found between calcium clearance and sulfate excretion in dogs, reported previously (34). A similar linear relationship is seen when radiostrontium clearance is plotted against plasma sulfate concentration.

3. The effect of other ions on the strontiuretic action of sulfate. Since it is known that administration of calcium leads to increased strontium excretion $(8,18,24)$, it was important to determine that the increase in radiostrontium clearance was not the result of the calcium present in most of

TABLE III

Effect of sulfate infusion on excretion of alkaline earth cations at decreasing urine flow in Dog $H$ (13.7 kg)

\begin{tabular}{|c|c|c|c|c|c|c|c|c|c|c|c|}
\hline \multirow[b]{2}{*}{ Time } & \multicolumn{3}{|c|}{ Plasma } & \multicolumn{5}{|c|}{ Urine } & \multirow{2}{*}{$\begin{array}{l}\mathrm{CCa} / \\
\text { GFR } \\
\text { ratio }\end{array}$} & \multirow{2}{*}{$\begin{array}{l}\mathrm{CMg}_{\mathrm{Mg}} \\
\mathrm{GFR} \\
\text { ratio }\end{array}$} & \multirow{2}{*}{$\begin{array}{l}\mathrm{Csr} / \\
\text { GFR } \\
\text { ratio }\end{array}$} \\
\hline & $\mathrm{Ca}$ & $\mathrm{Mg}$ & $\mathrm{Sr}^{85}$ & Flow & GFR & $\mathrm{Ca}$ & $\mathbf{M g}$ & $\mathrm{Sr}$ & & & \\
\hline \multicolumn{12}{|c|}{$0\left(25 \mu \mathrm{c} \mathrm{Sr}^{85}\right.$ i.v. creatinine prime; start Infusion $\left.\mathrm{I}, * 12 \mathrm{ml} / \mathrm{min}\right)$} \\
\hline $\begin{array}{l}118-140 \\
140-172 \\
172-202 \\
202-220\end{array}$ & $\begin{array}{l}1.86 \\
2.20 \\
1.85 \\
1.88\end{array}$ & $\begin{array}{l}0.74 \\
0.76 \\
0.75 \\
0.76\end{array}$ & $\begin{array}{l}1.67 \\
1.61 \\
1.46 \\
1.42\end{array}$ & $\begin{array}{l}3.7 \\
3.8 \\
7.2 \\
9.6\end{array}$ & $\begin{array}{l}49 \\
47 \\
50 \\
40\end{array}$ & $\begin{array}{l}0.14 \\
0.14 \\
0.10 \\
0.09\end{array}$ & $\begin{array}{l}0.28 \\
0.27 \\
0.17 \\
0.18\end{array}$ & $\begin{array}{l}0.65 \\
0.68 \\
0.42 \\
0.43\end{array}$ & $\begin{array}{l}0.006 \\
0.005 \\
0.007 \\
0.011\end{array}$ & $\begin{array}{l}0.027 \\
0.029 \\
0.033 \\
0.058\end{array}$ & $\begin{array}{l}0.029 \\
0.034 \\
0.042 \\
0.073\end{array}$ \\
\hline \multicolumn{12}{|c|}{$220\left(10 \mathrm{~g} \mathrm{Na}_{2} \mathrm{SO}_{4}\right.$ i.v. slowly; change to Infusion $\left.\mathrm{II}, * 3 \mathrm{ml} / \mathrm{min}\right)$} \\
\hline $\begin{array}{l}235-253 \\
253-271 \\
271-288\end{array}$ & $\begin{array}{l}2.09 \\
2.12 \\
2.13\end{array}$ & $\begin{array}{l}0.73 \\
0.80 \\
0.79\end{array}$ & $\begin{array}{l}1.55 \\
1.92 \\
1.74\end{array}$ & $\begin{array}{l}9.0 \\
7.9 \\
5.8\end{array}$ & $\begin{array}{l}40 \\
41 \\
33\end{array}$ & $\begin{array}{l}2.16 \\
2.92 \\
3.62\end{array}$ & $\begin{array}{l}0.79 \\
1.00 \\
1.14\end{array}$ & $\begin{array}{l}1.32 \\
4.34 \\
4.54\end{array}$ & $\begin{array}{l}0.24 \\
0.26 \\
0.30\end{array}$ & $\begin{array}{l}0.25 \\
0.24 \\
0.25\end{array}$ & $\begin{array}{l}0.20 \\
0.43 \\
0.46\end{array}$ \\
\hline
\end{tabular}

* Infusion $\mathrm{I}=$ glucose, $0.7 \mathrm{M} ;$; Infusion $\mathrm{II}=\mathrm{Na}_{2} \mathrm{SO}_{4}, \mathrm{Z}, 0.4 \mathrm{M}$. 
the infusions. Therefore, two experiments ( R2 and $\mathrm{S}$ ) were performed without the addition of calcium to the infusions, and in three others (D, $\mathrm{T}$ and $\mathrm{U})$, calcium was added only after several collection periods had been obtained (see Table I). One of these experiments is presented in detail in Table IV. In the first two blood samples, after starting the infusion of sulfate, plasma calcium is low due to omission of this ion from the infusion (34). Nevertheless, the strontium clearances in these periods are 45 and $42 \mathrm{ml}$ per $100 \mathrm{ml} \mathrm{GF}$. When calcium was added, plasma calcium returned to normal but radiostrontium clearance remained about the same ( 47 and $44 \mathrm{ml}$ per $100 \mathrm{ml} \mathrm{GF}$ ). Further documentation is provided in Figure 1, where the collection periods have been identified as to the presence or absence of hypocalcemia, and also of hypermagnesemia. Since magnesium salts may lead to increased calcium excretion, some increase in strontium clearance might also result. There do not appear to be any clear-cut differences between strontium clearances measured under these various conditions. Although hypocalcemia may modify the results slightly, it is clear that the major determinant of radiostrontium clearance in these experiments is sulfate excretion. These conclusions apply to clearance per $100 \mathrm{ml} \mathrm{GF}$ or uncorrected clearance, since changes in filtration rate were minor. The rate of sulfate excretion in the dogs undergoing water, glucose, or mannitol diuresis was less than $0.2 \mu$ mole per minute per

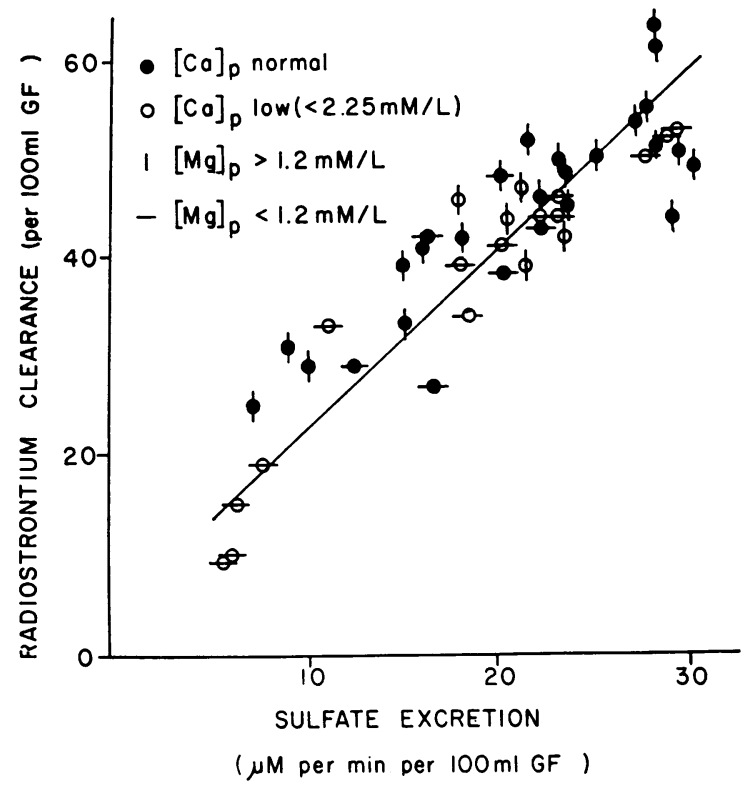

Fig. 1. Radiostrontium clearance as a function OF SUlFATE EXCRETION. Both parameters are expressed per $100 \mathrm{ml}$ of glomerular filtrate. Radiostrontium clearance was calculated without correction for proteinbinding. The relationship is approximately linear and is not significantly affected by the presence of hypocalcemia or hypermagnesemia.

$100 \mathrm{ml}$ of $\mathrm{GF}$, and therefore cannot be shown on this graph.

Calcium and magnesium clearances were also determined in most of these experiments. The effects of sulfate infusion on the excretion of these

TABLE IV

The effect of plasma calcium on the strontiuretic action of sulfate in Dog D $(8.8 \mathrm{~kg})$

\begin{tabular}{|c|c|c|c|c|c|c|c|c|c|}
\hline \multirow[b]{2}{*}{ Time } & \multicolumn{3}{|c|}{ Plasma } & \multicolumn{4}{|c|}{ Urine } & \multirow{2}{*}{$\underset{\text { ratio }}{\mathrm{C}_{\mathrm{Ca} / \mathrm{GFR}}}$} & \multirow{2}{*}{$\begin{array}{c}\mathrm{Cs}_{\mathrm{s}} / \mathrm{GFF} \\
\text { ratio }\end{array}$} \\
\hline & $\mathrm{Ca}$ & $\mathrm{SO}_{4}$ & $\mathrm{Sr}^{89}$ & Flow & GFR & $\mathrm{Ca}$ & $\mathrm{Sr}^{89}$ & & \\
\hline $\min$ & mmoles $/ L$ & mmoles/L & $\mu c / L$ & $\mathrm{ml} / \mathrm{min}$ & $m l / m i n$ & $\begin{array}{c}\text { umoles/ } \\
\text { min }\end{array}$ & $\mu \mathrm{c} / \mathrm{min}$ & & \\
\hline \multicolumn{10}{|c|}{$0\left(200 \mu \mathrm{c} \mathrm{Sr}{ }^{89}\right.$ i.v. start Infusion $\left.\mathrm{I},{ }^{*} 1 \mathrm{ml} / \mathrm{min}\right)$} \\
\hline $\begin{array}{r}0-630 \\
630-800\end{array}$ & 2.42 & 1.07 & & $\begin{array}{l}1.0 \\
0.7\end{array}$ & & & $\begin{array}{l}0.0444 \\
0.0186\end{array}$ & & \\
\hline \multicolumn{10}{|c|}{800 (Change to Infusion $\mathrm{II},{ }^{*} 13 \mathrm{ml} / \mathrm{min}$ ) } \\
\hline $\begin{array}{l}800-830 \\
830-846 \\
846-865 \\
865-889\end{array}$ & $\begin{array}{l}1.50 \\
1.55\end{array}$ & $\begin{array}{l}19.5 \\
21.2 \\
22.5\end{array}$ & $\begin{array}{l}9.1 \\
8.2 \\
7.4\end{array}$ & $\begin{array}{l}11.6 \\
11.8 \\
12.8 \\
14.0\end{array}$ & $\begin{array}{l}62 \\
60 \\
68\end{array}$ & $\begin{array}{l}21.2 \\
28.8 \\
30.8\end{array}$ & $\begin{array}{l}0.506 \\
0.225 \\
0.221 \\
0.214\end{array}$ & $\begin{array}{l}0.32 \\
0.29\end{array}$ & $\begin{array}{l}0.40 \\
0.45 \\
0.42\end{array}$ \\
\hline \multicolumn{10}{|c|}{889 (Change to Infusion III, ${ }^{*} 13 \mathrm{ml} / \mathrm{min}$ ) } \\
\hline $\begin{array}{c}889-905 \\
905-928 \\
970\end{array}$ & $\begin{array}{l}1.85 \\
2.28\end{array}$ & $\begin{array}{l}22.8 \\
22.9\end{array}$ & $\begin{array}{l}7.1 \\
6.8 \\
5.7\end{array}$ & $\begin{array}{l}14.6 \\
13.4\end{array}$ & $\begin{array}{l}60 \\
60\end{array}$ & $\begin{array}{l}28.9 \\
35.5\end{array}$ & $\begin{array}{l}0.201 \\
0.181\end{array}$ & $\begin{array}{l}0.25 \\
0.25\end{array}$ & $\begin{array}{l}0.47 \\
0.44\end{array}$ \\
\hline
\end{tabular}

*Infusion I $=\mathrm{NaCl}, 0.16 \mathrm{M}$; Infusion II $=\mathrm{Na}_{2} \mathrm{SO}_{4}, 0.090 \mathrm{M}, \mathrm{K}_{2} \mathrm{SO}_{4}, 0.008 \mathrm{M}, \mathrm{MgSO}_{4}, 0.002 \mathrm{M}$; Infusion III = same plus $\mathrm{CaCl}_{2}, 0.005 \mathrm{M}$. 
TABLE V

Radiostrontium excretion data

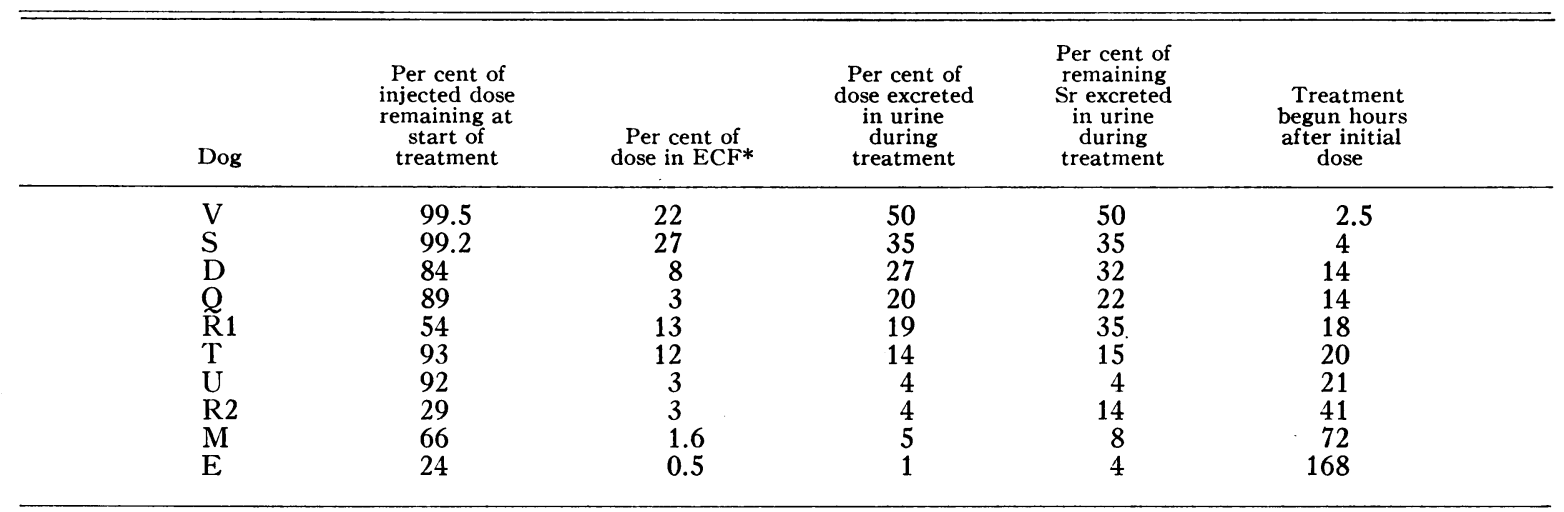

* Extracellular fluid.

ions (as exemplified in Tables III and IV) were in accord with previously reported findings (33, 34). A comparison of simultaneous clearances of alkaline earth cations under a variety of experimental conditions is under study.

This relationship also did not appear to be affected by variations in plasma or urine $\mathrm{pH}$, plasma potassium, or by the simultaneous infusion of mannitol, although a systematic study of these factors was not made.

4. The amount of radiostrontium mobilized by sulfate infusion. In Table $\mathrm{V}$ the ten experiments have been arranged in order of the interval between injection of isotope and commencement of the sulfate infusion. The fraction of the administered isotope remaining at the onset of therapy was determined as follows: Fecal excretion was measured directly in Dogs E, M, Q, R2 and U. In D, $\mathrm{S}$ and $\mathrm{V}$, stools were not passed in the interval between injection of isotope and sulfate infusions. In $\mathrm{R} 1$ and $\mathrm{T}$ the stool samples were lost. Since fecal excretion of parenterally administered radiostrontium is, on the average, equal to urinary excretion in normal dogs (37), the amount of isotope collected in the urine was doubled in these five experiments in order to obtain an approximate estimate of the radiostrontium excreted prior to treatment.

The percentage of the dose in the extracellular fluid was approximated by multiplying the percentage per liter of plasma at the start of the infusion by one-fifth of the body weight.

The percentage excreted in the urine during the infusion was measured directly. The data in
Table II establish that only a small fraction of this amount would have been excreted during this period without therapy.

The amount excreted in the urine during therapy exceeds the amount of isotope estimated to be in the extracellular fluid by twofold or more in five of the ten experiments. Plasma radiostrontium concentration at the end of the infusion was usually about one-half of its value at the beginning, or less. These observations establish that part of the excreted isotope was derived from sources outside of the extracellular fluid, despite the approximations involved. The efficacy of therapy may be evaluated by calculating the percentage of the remaining radiostrontium removed. As the table indicates, early therapy may remove as much as half of the body burden. Within a day, however, the remaining isotope becomes less accessible and only a small fraction can be mobilized in this manner. One week after injection, only 4 per cent of the remaining strontium was excreted during a prolonged (20 hour) infusion. These estimates are subject to some uncertainty regarding fecal excretion of isotope, and the amount of isotope remaining in the bowel.

No toxic effects were observed in these experiments, despite the large volumes infused, except when calcium or magnesium was omitted and symptoms of deficiencies of these cations developed (34).

\section{DISCUSSION}

These results indicate that sulfate is highly effective in augmenting the renal clearance of radio- 
active strontium. If administered early, it significantly reduces the retention of an injected dose in dogs. In comparison with other agents which have been examined, sulfate must be given in enormous quantities. Unlike most other agents, however, sulfate can be administered in such amounts without toxic effects, provided that deficiencies of calcium, magnesium and potassium are prevented by adding these cations to the infusion (34). In the presence of normal renal function, sulfate is cleared rapidly and is therefore less likely to produce overexpansion of the extracellular fluid than is isotonic sodium chloride solution.

It remains to be determined whether these results in animals can be duplicated in man. With respect to the effects upon renal clearance, there is little reason to doubt that a similar relationship obtains, since the effects of sulfate infusion upon calcium clearance are comparable in the two species (unpublished observation). The rate of removal of radiostrontium from the extracellular fluid may well be lower in man, because the increase in extracellular fluid volume from $\log$ to man is several fold greater than the increase in renal excretory capacity. On the other hand, the extent of skeletal deposition of radiostrontium in well nourished adults is less (38) than that in the dogs employed in this study. The net effect of these various differences between the two species cannot be assessed.

Schubert (5) has previously suggested that sulfate might be effective in promoting strontium excretion, by virtue of the lower solubility of strontium sulfate than calcium sulfate. This argument does not seem relevant because, unless carrier strontium is given, the product of strontium and sulfate concentrations in plasma or urine cannot conceivably approach the solubility product of this salt, $10^{-6.5}$ (at zero ionic strength and $25^{\circ} \mathrm{C}$ ) (36). The concentration of strontium in normal plasma is approximately $0.3 \times 10^{-7} \mathrm{M}(6)$. Furthermore, sulfate infusion has a comparable effect upon magnesium excretion (33), despite the high solubility of magnesium sulfate. On the other hand, the reported effect of orally administered sulfate in decreasing the absorption of carrier strontium from the gut (42) is probably related to precipitation of $\mathrm{SrSO}_{4}$, since strontium concentration in the gastrointestinal contents is elevated under these conditions. A single animal given carrier-free $\mathrm{Sr}^{90}$ and sulfate orally exhibited a 34 per cent reduction in skeletal $\mathrm{Sr}^{90}$ retention (43). Here the observed result may have been due to an effect of absorbed sulfate on urinary excretion of strontium, or due to impaired intestinal reabsorption of the strontium sulfate complex.

The mechanism by which parenterally administered sodium sulfate promotes strontium excretion by the kidney is not entirely clear. Several lines of evidence indicate that it is related to the formation of an electrostatic complex between strontium ions and sulfate ions, even though such a complex has apparently not been shown to exist. 1) The effects are qualitatively and quantitatively similar to the previously reported changes in calcium and magnesium clearance during sulfate infusion. 2) The dissociation constants of $\mathrm{CaSO}_{4}$ and $\mathrm{MgSO}_{4}$ are almost identical, being $0.06 \mathrm{M}$ at ionic strength $0.16(36)$. 3) Sodium salts of other multivalent anions, such as ferrocyanide, also promote strontium excretion (unpublished observations).

The simplest interpretation is that strontium, when electrostatically paired with sulfate, is not reabsorbed by the renal tubules. However, it is difficult to conceive how this phenomenon can account for almost complete inhibition of radiostrontium reabsorption. Assuming that the dissociation constant of the strontium sulfate ion-pair is identical with that of calcium sulfate, only approximately one-half of urinary radiostrontium will be paired with sulfate, as calculated previously for calcium (34). Yet strontium excretion is increased many fold. Further studies of the mechanism of this effect are needed.

Protein-binding of radiostrontium was determined (44) in 3 control plasma samples and in 13 samples obtained during sulfate infusion. The ratio of ultrafiltrate strontium to plasma strontium was calculated, ignoring corrections for plasma water and the Donnan factor, which are opposite in direction and magnitude. In the three control samples, ratios of $0.68,0.69$ and 0.67 were obtained. During sulfate diuresis, the mean ratio was $0.82 \pm 0.05$ (SD). This decrease in protein-binding of strontium, previously found for calcium, is due to the increased ionic strength resulting from sulfate, as is demonstrated in results published elsewhere (45). The difference between the ratio for radiostrontium and that for 
calcium in the same samples averaged $0.06 \pm 0.05$ $(\mathrm{SD}, \mathrm{n}=10)$, i.e., calcium may be slightly more strongly bound to plasma protein than is strontium. Although this difference is of borderline significance statistically, these results are in accord with previous data $(6,7,46)$.

A clearance of radiostrontium of $82 \mathrm{ml}$ per 100 $\mathrm{ml} \mathrm{GF}$ would therefore indicate complete excretion of filtered isotope under the conditions of these experiments. The highest clearance observed was $64 \mathrm{ml}$ per $100 \mathrm{ml} \mathrm{GF}$, indicating excretion of approximately 80 per cent of the filtered isotope. No evidence for renal tubular secretion of strontium was obtained.

The minor influence of hypocalcemia upon the relationship depicted in Figure 1 seems surprising, since it is known that administration of calcium leads to augmented radiostrontium excretion. However, the calcium clearance in a sulfate-loaded animal, in contradistinction to that of a normal animal, is independent of the plasma calcium concentration (34). Thus, calcium administration leads to an increase in calcium excretion, but under these conditions it fails to influence calcium clearance. Radiostrontium clearance is also unaffected (see Table IV).

It does not necessarily follow that the efficacy of therapy is unaffected by the level of plasma calcium. Even though radiostrontium clearance remains constant, the rate of radiostrontium excretion during sulfate infusion may be related to the plasma calcium. This would be the case, for example, if radiostrontium were mobilized from skeletal deposits more rapidly in the presence of hypocalcemia. Attempts to settle this point were unsuccessful, because of the variability between dogs and the unpredictable rate of decline of plasma radiostrontium in any given dog. In practice, the addition of calcium to the infusion is necessary in order to prevent symptomatic hypocalcemia.

This mode of therapy of radiostrontium poisoning, therefore, does not fall in the category of "decalcification therapy" (3). It is possible that prolonged administration of sulfate in smaller dosage without calcium might accomplish a degree of skeletal demineralization which would prove effective in mobilizing long-standing skeletal deposits of radiostrontium or other radioelements. A preliminary study employing oral methionine or thiosulfate to augment urinary sulfate excretion, has been reported in abstract form (1). Calcium intake in this study was not reduced sufficiently to permit a large negative balance to occur. In theory, however, any degree of skeletal decalcification can be induced by prolonged sulfate administration, as for example by intravenous injections of hypertonic sodium sulfate several times daily. The question is whether skeletal radiostrontium deposits will be mobilized early or late in such a procedure; in other words, whether the ratio of radiostrontium to calcium in the urine will pass through a peak value soon after instituting therapy or remain at a low value indefinitely. This problem remains to be elucidated.

The properties of an ideal agent for removing radiostrontium have been discussed by Schubert (5). It was assumed that the fraction of circulating strontium bound by the agent was a measure of its efficiency. More practical criteria should include two properties; the maximum strontium clearance attainable and the rate of removal of radiostrontium from bone. With respect to the former criterion, sulfate appears to be unexcelled; however, it is distinctly limited in its ability to mobilize skeletal deposits. The combined use of sulfate and skeletal dimineralizing agents may prove to be an effective form of therapy for radiostrontium poisoning.

\section{SUM MARY}

Carrier-free isotopes of strontium, $\mathrm{Sr}^{85}$ and $\mathrm{Sr}^{89}$, were injected intravenously into dogs. At intervals of 2.5 to 168 hours later, solutions containing sulfate were infused for 2 to 20 hours. The rate of urinary radiostrontium excretion immediately increased 6- to 40-fold. Radiostrontium clearance per $100 \mathrm{ml}$ glomerular filtrate increased linearly with sulfate excretion. The fraction of filtered strontium excreted reached 80 per cent as compared with a normal value of less than 10 per cent. During sulfate infusion, 22 to 50 per cent of the estimated amount of isotope remaining was excreted in the urine, provided that therapy was instituted within 18 hours of injection. When therapy was delayed, less than 15 per cent of the remaining radiostrontium was removed. In half of the experiments, the amount of isotope excreted in the urine during sulfate infusion was more than 
twice the amount estimated to be in the extracellular fluid, indicating that deposits of radiostrontium were mobilized from the skeleton and/or the tissues.

\section{ACKNOWLEDGMENT}

We are indebted to Sylvia E. Butler and Mary Jane Ford for valuable technical assistance.

\section{REFERENCES}

1. Walser, M., Payne, J. W., and Browder, A. A. Mobilization of radiostrontium with sulfate, thiosulfate, and methionine. Clin. Res. 1960, 8, 35.

2. Walser, M. Diffusible complexes of metal ions (abstract). Bull. Johns Hopk. Hosp. 1959, 104, 200.

3. Schubert, J. Removal of radioelements from the mammalian body. Ann. Rev. nuclear Sci. 1955, 5, 369.

4. Ito, Y., Tsurufuji, S., Ishidate, M., Tamura, Z., and Takita, H. Effect of rhodizonic acid on the excretion of radioactive strontium. J. Pharmacol. (Kyoto) 1956, 76, 1406.

5. Schubert, J. Limitations of chelating agents for the treatment of acute radiostrontium poisoning. Atompraxis 1958, 4, 393.

6. Harrison, G. E., Raymond, W. H. A., and Tretheway, H. C. The metabolism of strontium in man. Clin. Sci. 1955, 14, 681.

7. Chen, P. S., Jr., and Neuman, W. F. Renal reabsorption of calcium through its inhibition by various chemical agents. Amer. J. Physiol. 1955, 180, 632.

8. Spencer, H., Brothers, M., Berger, E., Hart, H. E., and Laszlo, D. Strontium ${ }^{85}$ metabolism in man and effect of calcium on strontium excretion. Proc. Soc. exp. Biol. (N. Y.) 1956, 91, 155.

9. Bacon, J. A., Patrick, H., and Hansard, S. L. Some effects of parathyroid extract and cortisone on metabolism of strontium and calcium. Proc. Soc. exp. Biol. (N. Y.) 1956, 93, 349.

10. Spencer, H., Laszlo, D., and Brothers, M. Strontium and calcium metabolism in man. J. clin. Invest. 1957, 36, 680 .

11. Comar, C. L., Wasserman, R. H., Ullberg, S., and Andrews, G. A. Strontium metabolism and strontium-calcium discrimination in man. Proc. Soc. exp. Biol. (N. Y.) 1957, 95, 386.

12. Sacher, G. The excretion, retention, distribution and clinical effects of strontium ${ }^{89}$ in the dog. Part II. Statistical analysis of excretion and retention of strontium $^{89}$ for individual dogs. Atomic Energy Comm. Report CH-3866, 1946.

13. Schubert, J., and Wallace, H., Jr. The effect of zirconium and sodium citrate on the distribution and excretion of simultaneously injected thorium and radiostrontium. J. biol. Chem. 1950, 183, 157.

14. Ito, Y., Tsurufuji, S., Murai, E., Ishibashi, S., Ishidate, M., and Tamura, Z. Detoxication and ex- cretion of radioactive strontium. II. Effect of sevcral organic acids having chelating ability. Chem. pharmaceut. Bull. (Tokyo), 1958, 6, 92.

15. Ito, Y., Tsurufuji, S., Ishibashi, S., Ishidate, M., Tamura, Z., and Takita, H. Detoxication and excretion of radioactive strontium. III. Effect of tricarballylic and lactic acids. Chem. pharmaceut. Bull. (Tokyo) 1958, 6, 34.

16. Ito, Y., Tsurufuji, S., Shikita, M., and Ishibashi, S. Detoxication and excretion of radioactive strontium. IV. Effect of sodium calcium citrate and the mode of action of citrate. Chem. pharmaceut. Bull. (Tokyo) 1958, 6, 287.

17. Cohn, S. H., Gong, J. K., and Milne, W. L. Experimental treatment of poisoning from fission products. Ability of chemical agents to alter the uptake and retention of fission products in animals exposed to radioactive fall-out. Arch. industr. Hlth 1956, 14, 533.

18. Therapy of radioelement poisoning. Atomic Energy Comm. Report ANL-5584, 1956.

19. Ray, R. D., Stedman, D. E., and Wolff, W. K. Bone metabolism. III. The effect of various diets on the mobilization of strontium from the rat skeleton. J. Bone Jt Surg. 1956, 38-A, 637.

20. Lindenbaum, A., Rosenthal, M. W., and Freid, J. F. Progress report: Radiostrontium removal. Atomic Energy Comm. Report ANL-5732, 1957, p. 134.

21. Spencer, H., Samachson, J., Kabokow, B., and Laszlo, D. Factors modifying radiostrontium excretion in man. Clin. Sci. 1958, 17, 291.

22. Goel, D. P., Skoryna, S. C., Yaffe, L., and Webster, D. R. Factors affecting the distribution and retention of radioactive strontium. Surg. Forum 1958, 8, 129.

23. Spencer, H., Samachson, J., and Laszlo, D. Effect of ethylenediaminetetraacetic acid on radiostrontium excretion in man. Proc. Soc. exp. Biol. (N. Y.) 1958, 97, 565.

24. Kawin, B. Effects of stable calcium and strontium on deposition of calcium-45 and strontium-89 in bone. Experientia (Basel ) 1959, 15, 313.

25. Charles, M. L., and Laszlo, D. The effectiveness of oral ammonium chloride on increased excretion of radio-strontium in man. Int. J. appl. Radiat. 1959, 5, 253.

26. Kroll, H., Jurgens, H., Gordon, M., Segal, E., and Saunders, A. The development of chelating agents for enhancing the urinary excretion of strontium. Atomic Energy Comm. Report AECU-4322, 1959.

27. Rosenthal, M. W. Radioisotope absorption and methods of eliminations: Factors influencing elimination from the body in Symposium on Radioisotopes in the Biosphere, R. S. Caldecott and L. A. Snyder, Eds. Minneapolis, Univ. of Minnesota Press, 1960, p. 541.

28. Catsch, A., and Melchinger, H. Untersuchungen über therapeutische Möglichkeiten bei Vergiftungen mit radioaktiven Spaltprodukten. V. Mitteilung: Der Einfluss von Chelatbildnern auf das biologische 
Verhalten von Radiostrontium. Strahlentherapie 1959, 108, 63.

29. Catsch, A., and Melchinger, H. Untersuchungen über therapeutische Möglichkeiten bei Vergiftungen mit radioaktiven Spaltprodukten. VI. Mitteilung: Die Beeinflussung des Verhaltens von Radiostrontium durch Erdalkalisalze. Strahlentherapie 1959, 109, 561 .

30. Moskalev, Y. I., and Budko, L. N. Effect of complexproducers on excretion of radioactive isotopes (strontium, yttrium and cerium) (abstract). Nuclear Sci. 1959, 13, 2674.

31. Looney, W. B., Maletskos, C. J., Helmick, M., Reardan, J., Cohen, J., Buchanan, J., Merrill, J., and Guild, W. A study of the dynamics of strontium and talcium metabolism and removal. Proc. Second United Nations Conf. on Peaceful Uses of Atomic Energy 1959, 24, 143.

32. Talmage, R. V., and Elliott, J. R. Effect of time of injection on removal of CA-45 and SR-85 by peritoneal lavage. Proc. Soc. exp. Biol. (N. Y.) 1958, 99, 306.

33. Walser, M., and Browder, A. Effect of sulfate on physical state and renal excretion of divalent cations (abstract). J. clin. Invest. 1958, 37, 940.

34. Walser, M., and Browder, A. A. Ion association. III. The effect of sulfate infusion on calcium excretion. J. clin. Invest. 1959, 38, 1404.

35. Smith, J. W. Strong electrolyte solutions. Sci. Progr. 1958, 46, 653.

36. Bjerrum, J., Schwarzenbach, G., and Sillen, L. G. Stability constants. Chem. Soc. (London) 1957, 1958, Special publ. nos. 6 and 7.

37. Stover, B. J., and Atherton, D. R. Metabolism of $\mathrm{Sr}^{20}$ in adult beagle dogs. Proc. Soc. exp. Biol. (N. Y.) 1958, 99, 201.
38. Bauer, G. C. H., and Ray, R. D. Kinetics of strontium metabolism in man. J. Bone Jt Surg. 1958, 40-A, 171.

39. Schulert, A. R., Peets, E. A., Laszlo, D., Spencer, H., Charles, M., and Samachson, J. Comparative metabolism of strontium and calcium in man. Int. J. appl. Radiat. 1959, 4, 144.

40. Walser, M. Determination of free magnesium ions in body fluids. Improved methods for free calcium ions, total calcium, and total magnesium. Analyt. Chem. 1960, 32, 711.

41. Walser, M. Determinations of inorganic sulfate in body fluids with barium chloranilate. In preparation.

42. MacDonald, W. S., Nusbaum, R. E., Ezmirlian, F., Barbera, R. C., Alexander, G. V., Spain, P., and Rounds, D. E. Gastro-intestinal absorption of ions. I. Agents diminishing absorption of strontium. J. Pharmacol. exp. Ther. 1952, 104, 348.

43. MacDonald, N. S., Spain, P. C., Ezmirlian, F., and Rounds, D. E. The effects of calcium and phosphate in foods on radiostrontium accumulation. J. Nutr. 1955, 57, 555.

44. Toribara, T. Y., Terepka, A. R., and Dewey, P. A. The ultrafiltrable calcium of human serum. I. Ultrafiltration methods and normal values. J. clin. Invest. 1957, 36, 738.

45. Walser, M. Ion association. I. The effect of multivalent anions on the protein bound and complexed calcium in serum. J. cell. comp. Physiol. 1960, 55, 245.

46. Samachson, J., and Lederer, H. Comparative ultrafiltration of calcium and strontium in serum. Proc. Soc. exp. Biol. (N. Y.) 1958, 98, 867. 